\title{
The effect of Pseudomonas chlororaphis subsp. aurantiaca strain Q16 able to inhibit Fusarium oxysporum growth on potato yield
}

\author{
Dragana Latković $c^{4}$ Mira Starović ${ }^{1}$ \\ ${ }^{1}$ Institute for Plant Protection and Environment, Belgrade, Serbia \\ ${ }^{2}$ Institute of Soil Science, Belgrade, Serbia \\ ${ }^{3}$ Military Medical Academy, Belgrade, Serbia \\ ${ }^{4}$ University of Novi Sad, Faculty of Agriculture, Serbia
}

Dobrivoj Poštić ${ }^{1 *}$. Dragana Jošić ${ }^{2} \cdot$ Zorica Lepšanović $^{3}$ Goran Aleksić ${ }^{1}$.

\begin{abstract}
Summary: This study assesses the potential of antibiotics-producing Pseudomonas cblororaphis strains to increase potato yield and to inhibit the mycelial growth of phytopathogenic fungi Fusarium oxysporum (Fo) isolated from potato. P. chlororaphis subsp. aurantiaia strain Q16 (Pch1Q16) caused the highest growth inhibition (67.07\%) of FoA2 isolate in vitro. In field trials the effect of PchlQ16 was measured as the number of stems, number and weight of tubers and a total potato yield of the Rudolph potato variety. Application of $P$. chlororaphis and the number of treatments exhibited a significant effect on the yield. Two treatments of PchlQ16 increased the total yield of tubers from $4.9 \%$ to $33.05 \%$, while four treatments from $9.3 \%$ to $92.35 \%$, compared to the control. Based on our field results we can recommend a frequent application of PchlQ16 (4 times) during potato growth season. The results of our in vitro experiment support these findings as the bacterial strain suppressed growth of F. oxysporm. In this investigation PchlQ16 was confirmed as an effective growth promoting agent in potato production and can be highly effective in prevention of F. oxysporum infection.
\end{abstract}

Key words: Fusarium oxysponm, inhibitory effects, Pseudomonas chloromaphis, rhizobacteria, Solamum tuberosum L.

\section{Introduction}

Potato (Solanum tuberosum L.) is one of the most important globally grown crops and has a significant role in human nutrition. The potato is the world's fourth largest food crop after wheat, rice and corn. In Serbia, potatoes are grown on approximately $40,000 \mathrm{ha}$, with relatively low average yields of around $7 \mathrm{tha}^{-1}$ in 2016 (FAOSTAT 2018). Such modest yield is the result of low output of the small farms that prevail in Serbia. At the same time, much higher yields of $30-40 \mathrm{tha}^{-1}$ are

Corresponding author

dobrivoj.postic@izbis.bg.ac.r

Acknowledgement:

This study was supported by the Ministry of Education, Science and Technological Development, Republic of Serbia, Projects III46007 and TR31018. Author would like to thank Mrs Svetlana Bajic-Raymond from Cotham School, England, for valuable comments and suggesting the text corrections.

Cite this article:

Poštić D., Jošić D., Lepšanović Z., Aleksić G., Latković D., Starović M. (2019). The effect of Psezdomonas chlororapbas subsp. aurantzaca strain Q16 able to inhibit Fusarum axysporim growth on potato yield. Ratan Pont, 56 (2), 41-48. obtained by a more intensive production on larger farms (Broćić et al., 2016).

About 40 soil-borne diseases affect potato worldwide and cause severe damage especially on tubers, the economically most important part of the plant (Gudmestad et al., 2007). Fusarium dry rot is caused by several Fusarim species, among them $F$. sambucinum, F. culmorum Fückel, F. avenaceum (Fries) Saccardo (Secor \& Salas, 2001; Daami-Remadi \& Mahjoug, 2006; Peters et al., 2008) including F. axysporum Schlech (Venter et al., 1992; Esfahani, 2005; Ocamb et al., 2007). Potato dry rot usually occurs during storage and can lead to losses in crop quality and yield. It is responsible for severe vascular wilts, and can cause tuber rot. Reduction of the yield caused by dry rot is on average $6 \%$, with possible losses up to $25 \%$ (Gashgari \& Gherbawy 2013), while almost complete loss of stored commercial potatoes varieties was reported in Turkey (Eken et al., 2000).

Fusarium wilt is mainly managed with chemical soil fumigation and resistant cultivars (Recep et al., 2009). However, synthetic fungicides used to fumigate soil before planting, particularly methyl bromide, lead to 
residue problems and accumulation of toxic pollutants in soil and water (Bunker \& Mathur 2001). The issues with controlling Fusarium wilt have led to research in biological control, resulting in the development of biopesticides for controlling Fusarium wilt without causing environmental pollution (Organisation for Economic Cooperation and Development 2009). Some strains of Bacillus subtilis and Pseudomonas fluorescens are reported to have reduced Fusarium wilt of different plants host (Jamali et al., 2004; Khorsani \& Safaie, 2008).

Plant growth promoting (PGP) rhizobacteria have a potential for improving yield and for suppressing soilborne pathogens (Backer et al., 2018). Many soil microorganisms, including Pseudomonas spp., produce different compounds with antifungal and antibacterial properties such as antibiotics, iron-chelating siderophores, cyanide and enzymes (Sindhu \& Dadarwal, 2001; Backer et al., 2018). These secondary metabolites have been involved in plant growth stimulation and disease control and their combination is essential for effectiveness of some strains against phytopathogens (Costa et al., 2009; Selin et al., 2010). Susilomati et al. (2011) reported that screening of Pseudomonas sp. indigenous to rhizosphere of soybean showed biocontrol activity against soil-borne fungi, mainly F. oxysporum. Many Pseudomonas strains are known to produce antibiotics such as phenazines (PHZ), pyrrolnitrin (PRN), pyoleuteorin (PLT), and 2,4-diacetyl phloroglucinol (DAPG). The role of PH' in biological control of three Colletotrichum lindemuthianum races using $P$. chlororaphis PCL1391 and P. fluorescens WCS365 (Bardas et al., 2009) and cypress canker by $P$. chlororaphis subsp. aureofaciens strain M71 (Raio et al., 2011) were reported. Different DAPG-producing P. fluorescens were involved in growth suppression of the different $F$. oxysporum subspecies: Fo f. sp. pisi (Landa et al., 2002), Fo f. sp. ciceri (Saikia et al., 2009), Fo f. sp. bycopersici (Manikamdan et al., 2010) and Fo f. sp. cubense (Selvaraj et al., 2014).

In Serbia, phenazines production of Pseudomonas spp. was assessed and significant amounts of phenazine-1carboxylic acid (PCA) and 2-hydroxy-phenazine-1carboxylic acid (2-OH-PCA) were quantified. A PCR confirmation of the presence of phenazines was revealed. All phenazine-producers, including $P$. chlororaphis strain Q16, were effective against phytopathogenic fungi (Jošić et al., 2012; 2015). Additional high enzymatic activities, a production of siderophores, HCN, IAA and AHLs, as well as good phosphosolubilization capacity placed it among the most promising PGP strains (Jošić et al., 2015).

In this study we tested the inhibitory effects of five PGP Pseudomonas chlororaphis strains to F. oxysporum isolated from potato ( $\left.F_{O} A 2\right)$ and the effect of metabolites of $P$. chlororaphis subsp. aurantiaca strain Q16 (PchlQ16), as the best antagonist, on this fungal pathogen. In field trials, we tested treatment frequency of PchlQ16 on the growth promotion and yield of potato (variety Rudolph).

\section{Materials and Methods}

Microorganisms and growth conditions

The Fusarium oxysporum isolate A2 (FoA2) used in this experiment (GenBank accession number MK621298) was previously isolated from potato tubers in Laboratory of Plant Disease in the Institute for Plant Protection and Environment in Belgrade, Serbia. FoA2 was maintained in Potato Dextrose agar (PDA) and used to assess antifungal activity of P. chlororaphis strains.

The complete genome sequences of used bacterial strains P. chlororaphis B25 (CP027753), three strains of P. chlororaphis subsp. aurantiaca Q16 (CP027718), K27 (CP027745) and M12 (CP027715) and P. chlororaphis subsp. aureofaciens strain C50 (CP027722) were deposited earlier (the accession numbers in DDBJ/503 EMBL/GenBank) (Biessy et al., 2019). Bacterial strains were grown on King B and Waksman media (Jošić et al., 2012).

\section{In vitro antifungal assay}

The screening test for antagonism in vitro was performed on Waksman agar medium by dual culture method (Wolf et al., 2002). Overnight cultures (ON) of the bacteria were optimized to $10^{7} \mathrm{CFU} \mathrm{mL}^{-1}$ on the basis of spectrophotometric data and placed $(10 \mu \mathrm{L})$ on the edges of Petri dishes, $3 \mathrm{~cm}$ distance from fungal mycelia placed as $1 \mathrm{~cm}$ plug in the center. The control variants contained only mycelia of $\mathrm{F}$. oxysporum on WA plates. The cultures were incubated at $25^{\circ} \mathrm{C}$, and growth of the fungi was allowed for 7 days after incubation for each of four replicates. The percentage inhibition of the growth of the fungi was calculated using the following formula: $100^{*}(1-\mathrm{R} 2 / \mathrm{R} 1)$, where R1 was the radial distance growth of the fungus in a control plate and R2 was the radial distance growth of the fungus in the bacterial treatment.

PchlQ16, showing the highest percentage of growth inhibition of FOA2, was selected for further investigation. The effects of ON culture, extracellular metabolites in cell-free supernatant (CFS), CFS treated with EDTA (ethylenediaminetetraacetic acid disodium salt dehydrate) (CFS-EDTA) and heat-treated cell-free supernatant (HT-CFS) on fungal growth were recorded. To obtain the supernatant fraction, optimized $\mathrm{ON}$ culture $\left(10^{8} \mathrm{CFU} \mathrm{mL}^{-1}\right)$ was centrifuged twice at 13000 $\mathrm{rpm}$ for 5 min., without and with filtration (filter tubes with microporous membrane $0.22 \mu \mathrm{m}$ ) (Merck Millipore Ltd.); one aliquot was treated with $1 \mathrm{mM}$ EDTA and one aliquot was heated at $70 \circ \mathrm{C}$ for $30 \mathrm{~min}$. The control variants contained only mycelia of FoA2 on WA and WA with $1 \mathrm{mM}$ EDTA added instead of bacterial culture/fraction. The assay was done as described for the screening test. All fungal inhibition assays were performed in four replicates and repeated three times. 
Table 1. Meteorological conditions during the potato growing season (2013 and 2014) in the area of western Serbia

\begin{tabular}{ccccc}
\hline \multirow{2}{*}{ Month } & \multicolumn{2}{c}{2013} & \multicolumn{2}{c}{2014} \\
\cline { 2 - 5 } & Temperature $\left({ }^{\circ} \mathrm{C}\right)$ & Rainfall $(\mathrm{mm})$ & Temperature $\left({ }^{\circ} \mathrm{C}\right)$ & Rainfall $(\mathrm{mm})$ \\
\hline April & 11.1 & 44.8 & 10.4 & 160.6 \\
May & 13.8 & 149.2 & 13.1 & 288.2 \\
Jun & 17.4 & 75.7 & 17.6 & 126.3 \\
July & 20.5 & 52.8 & 19.4 & 115.8 \\
August & 21.6 & 51.9 & 19.0 & 174.5 \\
September & 14.7 & 83.1 & 15.1 & 156.0 \\
Average /Total & 16.5 & 457.5 & 15.8 & 1021.4 \\
\hline
\end{tabular}

The effect of $P$. chlororaphis strain $Q 16$ on potato growth and yield

The effect of PchlQ16 and the frequency of treatments on potato yield of Rudolph variety were tested during two years: 2013 and 2014. The experiment was set up on a plot in Jagodnja in Mačva district, western Serbia (4419 '33 "N, $19^{\circ} 20^{\prime} 33^{\prime \prime}$ E, 759 m a. s. 1.) Field experiments were conducted in a split plot method with four replications. The total size of the experimental field was $144 \mathrm{~m}^{2}$ divided in 12 equally sized partitions $\left(12 \mathrm{~m}^{2}\right.$ each). 40 tubers were planted in each partition. Spacing between rows was $0.7 \mathrm{~m}$ and $0.35 \mathrm{~m}$ between plants in row. Potato tubers cv. Rudolph were planted manually in the first two weeks of April (5 April 2013 and 11 April 2014).

The soil on the experimental field was a type of acid and brown podzolic soil. The humus content in the surface layer was $3.40 \%$. The total nitrogen content of $0.27 \%$ classifies this as rich soil. The soil was acidic as the $\mathrm{pH}$ value in $\mathrm{H}_{2} \mathrm{O}$ was 4.35 , and 3.80 in $\mathrm{nKCl}$. The top soil laver provided readily available phosphorus (19.96 mg $0.1 \mathrm{~kg}^{-1}$ soil) and potassium $\left(\mathrm{K}_{2} \mathrm{O}\right.$ of 36.04 $\mathrm{mg} 0.1 \mathrm{~kg}^{-1}$ of soil) (personal communication). However, the content of the soluble potassium was insufficient to achieve high yield of potatoes, and this had to be compensated by adding fertilizers. According to the carbonate content, this is a poor calcareous soil. The precipitation level in the growing season was 457.5 in 2013 and $1021.4 \mathrm{~mm}$ in 2014, while the average temperature in those growing seasons was 16.5 and $15.8^{\circ} \mathrm{C}$, respectively (Table 1 ). Immediately prior to planting, the tubers were submerged in a $1 \mathrm{~L}$ culture $\left(10^{6}\right.$ CFU mL-1) of PchlQ16 (first treatment). During the vegetation period of potato, plants are watered at the stage of intensive vegetative development (second treatment); intensive tuber bulking (third treatment), and after flowering (fourth treatment) using a total of 5L $\left(10^{5} \mathrm{CFU} \mathrm{mL}^{-1}\right)$ culture. During the vegetation period, standard technology methods of growing potatoes were applied and six fungicide treatments were performed in May, lune and July using mixture of Metalaksil-m (40 $\left.\mathrm{g} \mathrm{kg}^{-1}\right)$ and Mankozeb $\left(640 \mathrm{~g} \mathrm{~kg}^{-1}\right)$ to protect from Late blight and Early blight. The number of primary stems per plants was measured 6.5 days after planting, while after harvest (6 September 2013 and 19 September 2014) the number of tubers per plant and the average weight of tubers per plants were measured. The total yield of tubers was calculated as fresh weight/ ha of the harvested tubers.

The obtained results were processed by the analysis of variance (ANOVA, F-test; $P \leq 0.05$ and $P \leq 0.01$ ) and the effect of factors. Correlations between the observed parameters were determined by Pearson correlation cocfficients (r). Data were processed by the STATISTICA program, version 8 (StatSoftInc, Tulsa, OK, USA).

\section{Results}

In vitro antifungal assay

Fungal growth inhibition screening test showed the inhibition ranging from 29 to $72 \%$ (Fig. 1). Four bacterial strains of PchlQ16: P. chlororaphis B25, P. chlororaphis subsp. aurantiaia M12 and $P$. chlororaphis subsp. aureofaciens $\mathrm{C} 50$ inhibited FoA2 isolate more than $50 \%$. The PchlQ16 was selected as the most effective strain for further study due to production of extracellular inhibitory substances.

Antagonistic activity of PchlQ16 against FoA2 was confirmed by additional testing using ON culture, cellfree supernatant, as well as CFS-treated with $1 \mathrm{mM}$ EDTA and heat-treated. The maximum inhibition rate

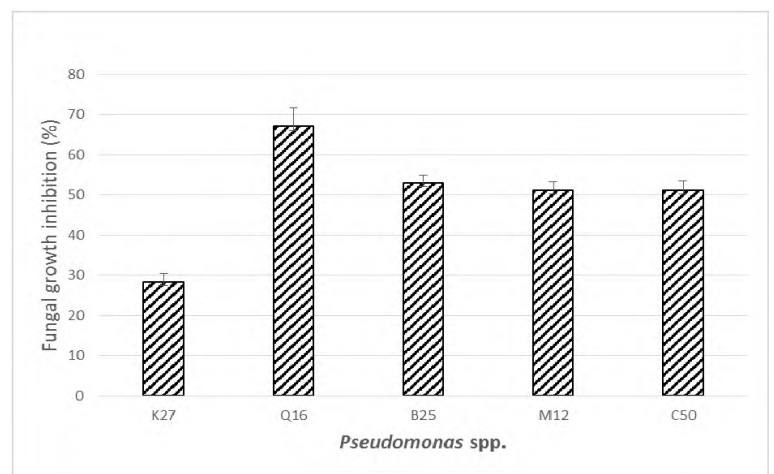

Figure 1. The effect of Pieudomonas chlororaphis strains on the growth of F. oxysporum A2 
was observed in the $\mathrm{ON}$ culture and was in concordance with a screening test, even when different concentrations of bacteria were used. FoA2 was inhibited by $67.1 \%$ in screening test $\left(10^{5} \mathrm{CFU} \mathrm{mL}^{-1}\right.$ inoculum) and $67.5 \%$ in the second test, with a $10 \times$ higher concentration (Table 2). All CFS fractions showed a significant decrease of FoA2 growth inhibition comparing to the ON culture. EDTA did not influence fungal growth at all, showing the same values as controls.

The effect of $P$. chlororaphis strain $Q 16$ on the growth and yield potato

Weather conditions during the vegetation period in 2014 (Table 1) were much more favourable for the growth of potatoes, compared to 2013. Analysis of the results regarding the number of primary stems per plant showed significant differences from the effect of PchlQ16 (factor A) or the number of treatment (factor B) as well as their interaction $(A \times B)$ (Table 3). Applying PchlQ16 twice during the potato growing season increased the number of stems per plant by $15.5 \%$ (in 2013) to $30.21 \%$ (in 2014) compared to the control. Using PchlQ16 four times during the growing seasons was even more effective, increasing the number of stems by $27.5 \%$ (in 2013) to $49.65 \%$ (in 2014) relative to control.

The lowest number of stems per plant in both years was recorded on a control variant $(K)$ without the use of PchlQ16 (Table 3). Number of stems per plant largely depends on the variety, cultivation technology, the size of seed tubers and physiological age. Number of stems per plant affects the development of above-ground weight, i.e. assimilation surface, the number of set tubers, or total yield (Poštić et al., 2012, Momirović et al., 2016).

Similar results were obtained when the number of tubers per plant was counted. Our results showed a very significant difference when either PchlQ16 (factor A) or the number of treatment (factor $B$ ) were taken into account as well as their interaction $(A \times B)$ (Table 4). Applying PchlQ16 twice during the potato growing season increased the number of tubers per plant by $16.3 \%$ (in 2013) and $38.43 \%$ (in 2014) compared to the
Table 2. The effect of $P$. chlororaphis strain Q16 on F. oxysporum A2

\begin{tabular}{|c|c|c|c|}
\hline \multirow{2}{*}{\multicolumn{2}{|c|}{ Treatment }} & \multicolumn{2}{|c|}{ F. oxysporum A2 } \\
\hline & & Growth $(\mathrm{mm})$ & Inhibition $(\%)$ \\
\hline & ontrol/ EDTA & $80.0 \pm 0.82$ & 1 \\
\hline \multirow{4}{*}{ Q16 } & ON culture & $26.0 \pm 1.63$ & $67.5^{*}$ \\
\hline & CFS & $33.8 \pm 0.96$ & 57.8 \\
\hline & CFS- EDTA & $35.5 \pm 1.29$ & 55.6 \\
\hline & H'T-CFS & $35.0 \pm 1.41$ & 56.2 \\
\hline
\end{tabular}

control. Using PchlQ16 four times during the growing seasons was found to increase the number of tubers per plant from $32.7 \%$ (in 2013) to $91.14 \%$ (in 2014), relative to control.

The lowest number of tubers per plant in both study years was recorded on the control variant (C) without the application of PchlQ16. Number of tubers per plant is a trait that largely depends on the variety, agro-ecological conditions, cultivation technologies and the size of seed tubers (Tadesse et al., 2001, Poštić et al., 2012, Momirović et al., 2016).

In contrast, the analysis of the average weight of tubers per plant (Table 5) showed no statistically significant difference caused by PchlQ16 (factor A), the number of treatment (factor B), and their interactions. Although the average weight of tubers is a varietal characteristic, it largely depends on the agro-ecological factors, cultivation practices, the number of above ground stems per plant and the number of tubers per plant (Tadesse et al., 2001).

The effect of PchlQ16 on the average weight of tubers per plant in both years was absent (Table 5), due to an increased number of tubers per plant (Table 4). Although the number of tubers per plant had grown, the average tuber weight per plant decreased and vice versa (Poštić et al., 2013).

The analysis of the total yield of tubers showed a highly significant difference with application of

Table 3. The number of primary stems per plant affected by P. chlororaphis Q16 and the frequency of treatment in 2013 and 2014

\begin{tabular}{|c|c|c|c|c|c|c|}
\hline \multirow{3}{*}{$\frac{\text { Year }}{\text { Treatment (B) }}$} & \multicolumn{6}{|c|}{ P. chlororaphis Q16 (A) } \\
\hline & \multicolumn{3}{|c|}{2013} & \multicolumn{3}{|c|}{2014} \\
\hline & 2 & 4 & $\mathrm{C}$ & 2 & 4 & C \\
\hline Mean No & 3.57 & 3.94 & 3.09 & 3.75 & 4.31 & 2.88 \\
\hline \multirow[t]{2}{*}{ Index $(\%)$} & 115.50 & 127.50 & 100.00 & 130.21 & 149.65 & 100.00 \\
\hline & A & $\mathrm{B}$ & $\mathrm{AB}$ & A & $\mathrm{B}$ & $\mathrm{AB}$ \\
\hline $\mathrm{F}$ & $8.15^{\text {** }}$ & $7.89 * *$ & $4.12^{* * *}$ & $4.93^{* *}$ & $49.48^{* *}$ & $4.25^{* *}$ \\
\hline $\mathrm{LSD}_{0,05}$ & 0.45 & 0.36 & 0.63 & 0.35 & 0.28 & 0.49 \\
\hline $\operatorname{LSD}_{0,01}$ & 0.62 & 0.5 & 0.84 & 0.47 & 0.39 & 0.67 \\
\hline
\end{tabular}

\footnotetext{
** - significant at $0.01 ; *$ - significant at 0.05 ; ns - not significant; $\mathrm{C}$ - control variant
} 
Table 4. The number of tubers per plant affected by P. chlororaphis Q16 and frequency of treatment in 2013 and 2014

\begin{tabular}{lcccccc}
\hline & \multicolumn{7}{c}{ P. chlororaphis Q16 (A) } \\
\cline { 2 - 7 } Year & \multicolumn{7}{c}{ Q } & 2013 & \multicolumn{2}{c}{2014} \\
\hline Treatment (B) & 2 & 4 & $\mathrm{C}$ & 2 & 4 & $\mathrm{C}$ \\
\hline Mean No & 8.21 & 9.37 & 7.06 & 9.69 & 13.38 & 7 \\
Index (\%) & 116.30 & 132.7 & 100.00 & 138.43 & 191.14 & 100.00 \\
\cline { 2 - 7 } & $\mathrm{A}$ & $\mathrm{B}$ & $\mathrm{AB}$ & $\mathrm{A}$ & $\mathrm{B}$ & $\mathrm{AB}$ \\
$\mathrm{nyyyyyy}$ & $4.50^{* *}$ & $10.88^{* *}$ & $3.47^{* *}$ & $21.66^{* *}$ & $129.76^{* *}$ & $21.49^{* *}$ \\
LSD $_{0,05}$ & 1.21 & 0.99 & 1.71 & 0.84 & 0.68 & 1.18 \\
LSD $_{0,01}$ & 1.66 & 1.36 & 2.25 & 1.15 & 0.94 & 1.62 \\
\hline
\end{tabular}

** - significant at 0.01 ; * significant at 0.05 ; ns - not significant; $\mathrm{C}$ - control variant

Table 5. Average weight (g) of tubers per plant affected by P. chlororaphis Q16 and frequency of treatments in 2013 and 2014

\begin{tabular}{|c|c|c|c|c|c|c|}
\hline \multirow{3}{*}{$\begin{array}{l}\text { Year } \\
\text { Treatment (B) }\end{array}$} & \multicolumn{6}{|c|}{ P. chlororaphis Q16 (A) } \\
\hline & \multicolumn{3}{|c|}{2013} & \multicolumn{3}{|c|}{2014} \\
\hline & 2 & 4 & $\mathrm{C}$ & 2 & 4 & $\mathrm{C}$ \\
\hline Mean weight $(\mathrm{g})$ & 75.10 & 81.70 & 83.20 & 53.02 & 54.94 & 55.58 \\
\hline \multirow[t]{2}{*}{ Index $(\%)$} & 90.30 & 98.20 & 100.00 & 95.39 & 98.85 & 100.00 \\
\hline & A & $\mathrm{B}$ & $\mathrm{AB}$ & $\mathrm{A}$ & $\mathrm{B}$ & $\mathrm{AB}$ \\
\hline $\mathrm{F}$ & $0.03 \mathrm{~ns}$ & $2.75 \mathrm{~ns}$ & $0.38 \mathrm{~ns}$ & $0.09 \mathrm{~ns}$ & $0.25 \mathrm{~ns}$ & $0.08 \mathrm{~ns}$ \\
\hline $\mathrm{LSD} 0,05$ & 10.99 & 8.98 & 15.55 & 6.68 & 5.45 & 9.44 \\
\hline LSD0,01 & 15.08 & 12.31 & 21.33 & 9.15 & 7.48 & 12.95 \\
\hline
\end{tabular}

** - significant at 0.01 ; * - significant at 0.05 ; ns - not significant; $\mathrm{C}$ - control variant

Table 6. Total yield of tubers ( $\left.\mathrm{t} \mathrm{ha}^{-1}\right)$ affected by P. chlororaphis Q16 and the frequency of treatment in 2013 and 2014

\begin{tabular}{|c|c|c|c|c|c|c|}
\hline \multirow{3}{*}{$\frac{\text { Year }}{\text { Treatment (B) }}$} & \multicolumn{6}{|c|}{ P. chlororaphis Q16 (A) } \\
\hline & \multicolumn{3}{|c|}{2013} & \multicolumn{3}{|c|}{2014} \\
\hline & 2 & 4 & $\mathrm{C}$ & 2 & 4 & $\mathrm{C}$ \\
\hline Mean yield $\left(\mathrm{t} \mathrm{ha} \mathrm{a}^{-1}\right)$ & 28.10 & 29.30 & 26.80 & 20.53 & 29.68 & 15.43 \\
\hline \multirow[t]{2}{*}{ Index $(\%)$} & 104.90 & 109.30 & 100.00 & 133.05 & 192.35 & 100.00 \\
\hline & $\mathrm{A}$ & $\mathrm{B}$ & $\mathrm{AB}$ & $\mathrm{A}$ & $\mathrm{B}$ & $\mathrm{AB}$ \\
\hline $\mathrm{F}$ & $121.38^{* * *}$ & $76.96^{* * *}$ & $50.50^{* * *}$ & $88.67^{* *}$ & $396.56^{* * *}$ & $88.83^{* *}$ \\
\hline LSD0,05 & 0.93 & 0.76 & 1.31 & 1.02 & 0.83 & 1.44 \\
\hline LSD 0,01 & 1.27 & 1.04 & 1.80 & 1.40 & 1.14 & 1.98 \\
\hline
\end{tabular}

** - significant at 0.01 ; ${ }^{*}$ - significant at 0.05 ; ns - not significant; $\mathrm{C}$ - control variant

Table 7. A correlation between evaluated traits of potato $(n=6)$

\begin{tabular}{lcccc}
\hline & No. of primary stems per plant & No. of tubers per plant & Average tuber weight & Total yield \\
\hline No. of primary stems per plant & - & $0.918^{* *}$ & -0.156 & 0,653 \\
No. of tubers per plant & & - & -0.427 & 0.473 \\
Average tuber weight & & & - & 0.569 \\
Total yield & & & -
\end{tabular}

Pearson correlation coefficient: **⿰㇇⿰亅⿱丿丶丶 $\mathrm{P} \leq 0.001$, **⿰㇇⿰亅⿱丿丶丶 $\mathrm{P} \leq 0.01$, * $\mathrm{P} \leq 0.05$, respectively

PchlQ16 (factor A) and the number of treatment (factor $B)$, as well as their interaction $(A \times B)$ (Table 6). Applying PchlQ16 twice during the potato growing season increased the yield by $4.9 \%$ (in 2013) and $33.05 \%$ (in 2014) compared to the control.

The lowest total tuber yield in both study years was recorded on the control variant $(C)$ without the use of PchlQ16. The yield of potato tubers depends on the genetic potential of the varieties, the number of above ground stems and the number of tubers per plant (Knowles et al., 2003, Bus \& Wustman 2007, Poštić et al., 2012, Momirović et al., 2016).

Based on the correlation analysis, the correlation between the number of tubers per plant and the number of above-ground stems is high ( $p$ $=0.01)($ Table 7$)$. 


\section{Discussion}

Although no natural infection with Fo was observed in the field trial during the two years, PchlQ16 can be applied to prevent infection with Fusarium spp. This conclusion is based on the inhibition rate of $67 \%$ and $56 \%$ for $\mathrm{FoA} 2$, when $\mathrm{ON}$ culture and different cell-free supernatants were applied respectively. In experiments on the cardoon (Cynara cardunculus L.) disease caused by A. temissima (Jošić et al., 2012), PchlQ16 exhibited a very similar inhibition rate for in vitro mycelial growth on WA and for the disease suppression in vivo under gnotobiotic conditions (about $43 \%$ ). The value for heat-stable antifungal factors was lower $(34 \%)$, similarly to results in this assay, with a decrease from 67 to $56 \%$ for FoA2.

Cell-free supernatant significantly reduced the inhibition percent of FoA2 mycelial growth comparing to ON culture. Heat-treated cell-free supernatant (HTCFS) was used in order to explore the thermo-resistance of the molecule responsible for antagonistic activity of PchlQ16. Similar results for CFS and treated CFS suggest that resistance to EDTA, as non-specific inhibitor of neutral- or metallo-proteases, and the thermo-resistance of extracellular metabolites indicate to non-protein antifungal factors. One possible explanation could be that more than one compound is responsible for the inhibition of Fo. The mycelial growth inhibition of about 40 and $55 \%$ caused by all CFS fractions and more than $67 \%$ of ON culture for FoA2, identify a potential of PchlQ16 for biological control of Fo in field conditions.

All $P$. chlororaphis strains in this study showed the ability to reduce F. oxysporum growth, four of them more than $50 \%$. In our previous study, we reported the highest phenazines production by PchlQ16 among tested strains (Jošić et al., 2012). Most research on P. chlororaphis has focused on antibiotic production and its antifungal activities to phytopathogens. Fungal growth inhibition and reduction of F. oxysporum f. sp. radici-bycopersici pathogenicity on tomato plantlets are reported for P. chlororaphis M71 (Puopolo et al., 2011). P. chlororaphis strain PA23, which is able to protect canola against sclerotinia stem rot caused by Sclerotinia sclentionum, produced several antibiotics pyrrolnitrin, PCA, 2-hydroxy-phenazine, and other exometabolites such as hydrogen cyanide ( $\mathrm{HCN}$ ) and degradative enzymes protease, lipase and chitinase (Poritsanos et al., 2006; Selin et al., 2010).

Besides antibiotic production, other extracellular metabolites are important in effective biocontrol and plant growth stimulation. During assessment of DAPGproducing $P$. fluorescens for the management of $F$. axysporum on watermelon, Meyer et al. (2016) demonstrated that $P$. fluorescens strains, even in vitro inhibiting $F$. oxysporum f. sp. niveum, resulted in some inhibition of vine growth in the field and were not effective for enhancing plant vigor or suppressing fungal infection on watermelon. In our earlier study of the capability to control powdery mildew in wheat, seeds treatment with P. chlororaphis Q16 improved the plant biomass and $\mathrm{N}$ content and decreased powdery mildew disease incidence (Pivic et al., 2015). The antibiotics production, in addition to other PGP traits, can be the favorable traits of PchlQ16 for the biocontrol of Fo in potato production.

Field experiments indicated a positive effect of this strain on the potato growth in two growing seasons. Favourable average temperatures in July and August, accompanied by an optimal amount of precipitation in 2014 , contributed to the higher crop productivity then in 2013 as the potatoes were at the stage of intensive tuber bulking. In addition, the higher precipitation value and optimum temperature in 2014 resulted in the increased activity of the microorganisms.

During 2013 PchlQ16 application increased the number of above ground stem per plant by $15.5 \%$ and $27.5 \%$; the number of tubers per plant by $16.3 \%$ and $32.7 \%$, and the total yield of tubers by $4.9 \%$ and $9.3 \%$ when applied twice and four times, respectively. In 2014 PchlQ16 application was significantly more effective as the number of above ground stem per plant increased by $30.21 \%$ and $49.65 \%$; the number of tubers per plant by $38.43 \%$ and $91.14 \%$; and the total yield by $33.05 \%$ and $92.35 \%$ compared to untreated control, when was applying twice and four times, respectively.

Using PchlQ16 four times during the growing seasons led to an increase in yield ranging from $9.3 \%$ (in 2013) to $92.35 \%$ (in 2014) compared to the control.

Based on our comprehensive results, we can recommend the use of PchlQ16 as a biological agent during the potato growth season. Further work is recommended to test the inhibition of Fusarium spp. in field conditions.

\section{References}

Backer, R., Rokem, J. S., Ilangumaran, G., Lamont, J., Praslickova, D., Ricci, E., Subramanian S. \& Smith, D. L. (2018). Plant Growth-Promoting Rhizobacteria: Context, Mechanisms of Action, and Roadmap to Commercialization of Biostimulants for Sustainable Agriculture. Frontiers in plant science, 9, $1473(1 / 17)$.

Bardas, G.A., Lagopodi, A.L., Kadoglidou, K. \& Tzavella-Klonari, K. (2009). Biological control of three Colletotrichum lindemuthiamum races using Pseudomonas cblororaphis PCL1391 and Pseudomonas fluorescens WCS365. Biological Control, 49(2), 139-145.

Biessy, A., Novinscak, A., Blom, J., Léger, G., Thomashow, L. S., Cazorla, F. M., Josic, D. \& Filion, M. (2019). Diversity of phytobeneficial traits revealed by whole-genome analysis of worldwide - isolated phenazine-producing Pseudomonas spp. Environ Microbiol, 21, 437-455.

Broćić, Z., Dolijanović, Z., Poštić, D., Milošević, D. \& Savić, J. (2016). Yield, Tuber Quality and Weight Losses During Storage of Ten Potato Cultivars Grown at Three Sites in Serbia. Potato Research, 59(1), 21-34.

Bunker, R.N. \& Mathur K. (2001). Integration of biocontrol agents and fingicide for suppression of dry root rot of Capsiam frutescens. Joumal of mycology and plant patbology, 31, 330-334.

Bus, C.B. \& Wustman, R. (2007). The Canon of Potato Science: 28. Seed Tubers. Potato Research, 50(3-4), 319-322.

Costa, R., van Aarle, I.M., Mendes, R. \& van Elsas, J.D. (2009). Genomics of pyrrolnitrin biosynthetic loci: evidence for conservation \& whole-operon mobility within Gram-negative bacteria. Emirommental Microbiology, 11(1), 159-175. 
Daami-Remadi, N. \& El Mahjoub, M. (2006). Présence en Tunisie d'isolats de Fusarium sambucinum résistants aux benzimidazoles. Biotechnology, Agronomy, Society and Emiromment, 10, 7-16.

Eken, C., Demirci, E. \& Sahin,F. (2000). Pathogenicity of the fungi determined on tubers from potato storages in Erzurum, Turkey. Jounal of Turkish Pbytopatbology, 29, 61-69.

Esfahani, M.N. (2005). Susceptibility assessment of potato cultivars to Fusarium dry tot species. Potato Research, 48, 215-226.

FAOSTAT (2018) Online Database (available at http://faostat.fao.org/. accessed May 28, 2018).

Gashgari, R. \& Gherbawy, Y. (2013). Pathogenicity of Some Fusarium Species Associated with Superficial Blemishes of Potato Tubers. Polish Joumal of Microbiology, 62(1), 59-66.

Gudmestad, N.C., Taylor, R.J. \& Pasche, J.S. (2007). Management of soilborne disease on potato. Australiasian Plant Patbology, 36(2), 109-115.

Jamali, F., Sharifi-Tehrani A, Okhovvat M, Zakeri Z. \& Saberi-Riseh R. (2004). Biological control of chickpea Fusarium wilt by antagonistic bacteria under greenhouse condition. Communications in agricultural and applied biological sciences, 69(4), 649-51.

Jošić, D., Protolipac, K., Starović, M., Stojanović, S., Pavlović, S., Miladinović, M. \& Radović, S. (2012). Phenazines producing Pseudomonas isolates decrease Alternaria temissima growth, pathogenicity and disease incidence on cardoon. Arcbives of Biological Sizences, 64 (4), 1495-1503.

Jošić, D., Cirić, A., Soković, M., Stanojković-Sebić, A., Pivić, R., Lepšanović, Z. \& Glamočlija, J. (2015). Antifungal Activities of Indigenous Plant Growth Promoting Pseudomonas spp. from Alfalfa and Clover Rhizosphere. Frontiers in Life Science, 8(2), 131 138.

Khorsani, G.A. \& Safaie,_A. N. (2008). Biological control of Fusarium wilt of potato using antagonistic strains of bacteria. Iramian Joumal of Plant Pathology, 44 (173), 1-21.

Knowles, R., Knowles, L. \& Kumar, G.N.M. (2003). Stem number \& set relationships for Russet Burbank, Ranger \& Umatilla Russet potatoes in the Columbia Basin. Potato Progress, 3(13), 1-4.

Landa, B.B., Mavrodi, O.V., Raaijmakers, J.M., McSpadden Gardener, B.B., Thomashow, L.S. \& Weller, D.M. (2002). Differential ability of genotypes of 2,4 - diacetylphloroglucinol producing Pseudomonas fluorestens strains to colonize the roots of pea plants. Applied and Emironmental Microbiology, 68(7), 3226 3237.

Manikamdan, R., Saravanakumar, D., Rajendran, L., Raguch\&er, T. \& Samiyappan, R (2010). Standardization of liquid formulation of Pseudomonas fluoresiens Pf1 for its efficacy against Fusarium wilt of tomato. Biological Control, 54(2), 8389.

Meyer, S. L. F., Everts, K. L., McSpadden Gardener, B., Masler, E.P., Abdelnabby, H.M.E. \& Skantar, A.M. (2016). Assessment of DAPG-producing Pseudomonas fluorescens for Management of Meloidogyne incognita and Fusarium oxysponumon Watermelon. Journal of Nematology, 48(1), 43-53.

Momirović, N., Broić, Z., Stanisavljević, R, Strbanović, R., Gvozden, G., Stanojković-Sebić A. \& Poštić, D. (2016). Variability of Dutch potato varieties under various agroecological conditions in Serbia. Genetika, 48(1), 109-124.

Ocamb, C.M., Hamm, P.B. \& Johnson, D.A. (2007). Benzimidazole resistance of Fusarium species recovered from potatoes with dry rot from storages located in the Columbia basin of Oregon and Wachington. American Journal of Potato Research, 84, 169-177.

Organisation for Eronomic Co-operation \& Development (2009). "Report of Workshop on the Regulation of Biopesticides: Registration \& Communication Issues". In: Seeris on Pesticides. http://www.oecd.org/chemicalsafety/pesticides-biocides/ biological pesticide registration.htm, No 44.

Peters, R.D., MacLeod, C., Seifert, K.A., Martin, R.A., Hale, L.R. Grau, C.R. \& MacInnis, S. (2008). Pathogenicity to potato tubers of Fusarium spp. isolated from potato cereal and forage crops. American Joumal of Potato Research, 85, 367-374.
Pivić, R., Starović, M., Delić, D., Rasulić, N., Kuzmanović, Đ., Poštić, D. \& Jošić, D. (2015). Bacterial antagonists Bacillus sp. Q3 and Pseudomonas chlororaphis Q16 capable to control wheat powdery mildew in wheat. Romanian Biotechnological Letters, 20(3), 10448 10460.

Poritsanos, N., Selin, C., Fern\&o,W.G.D., Nakkeeran, S. \& de Kievit T.R. (2006). A GacS deficiency does not affect Pseudomonas chlororaphis PA23 fitness when growing on canola, in aged batch culture or as a biofilm. Canadian Journal of Microbiology, 52, 11771188.

Poštić, D., Momirović, N., Dolijanović, Ż., Broćić, Z., Jošić, D., Popovic, T. \& Starović, M., (2012). Effect of Potato Tubers Origin \& Weight on the Yield of Potato Variety Desiree in Western Serbia. Field and Vegetable Crops Research, 49(3), 236-242.

Poštić, D., Starović, M., Popović, T., Bosnić, P., Stanojković-Sebić, A., Pivić, R. \& Jošić D. (2013). Selection and RAPD analysis of Pseudomonas spp. isolates able to improve biological viability of potato seed tubers. Genetika, 45(1), 237-249.

Puopolo, G., Raio, A., Pierson, L.S. \& Zoina, A. (2011). Selection of a new Pseudomonas chlororapbis strain for the biological control of Fusarium oxysponum f.sp.radicis lycopersici. Phytopathologia Mediternanea, 50, 228-235.

Raio, A., Puopolo, G., Cimmino, A., Danti, R., Della, R.G. \& Evidente, A. (2011). Biocontrol of cypress canker by the phenazine producer Pseudomonas dhlororaphis subsp. aureofaciens strain M71. Biological Controntrol, 58(2), 133-138.

Recep, K, Fikrettin, S., Erkol, D. \& Cafer, E. (2009). Biological control of the potato dry rot caused by Fusarium species using PGPR strains. Biological Control, 50(2), 194-198.

Saikia, R., Varghese, S., Singh, B.P. \& Arora, D.K. (2009). Influence of mineral amendment on disease suppressive activity of Pseudomonas fluoresrens to Fusarium wilt of chickpea. Microbiological Research, 16(4), 365-373.

Secor, G.A. \& Salas, B. (2001). Fusarium dry rot and fusarium wilt. In. Stevenson, W.R., Loria, F., Franc, G.D., Weingartner, D.P., editors. Compendium of potato diseases. St.Paul, mn, USA: APS Press.

Selin, C., Habibian, R., Poritsanos, N., Athukorala, S.N., Fern\&o, D. \& de Kievit, T.R. (2010). Phenazines are not essential for Pseudomonas chloronaphis PA23 biocontrol of Silerotinia silerotionum, but do play a role in biofiln formation. FEMS Mirrobiology Ecology, 71(1), 73-83

Selvaraj, S., Ganeshamoorthi, P., And, T., Raguchander, T., Seenivasan, N. \& Samiyappan, R. (2014). Evaluation of a liquid formulation of Pseudomonas fluorescens against Fusarium oxysporum f. sp. cubense and Helicotylenchus multicinctus in banana plantation. Biological Control, 59(3), 345-355.

Sindhu, S.S. \& Dadarwal, KR. (2001). Chitionlytic and cellulytic Pseudomonas spp. antagonistic to fungal pathogens enhances nodulation by Mesorbizobium spp. cicer in chickpea. Microbiological Research, 156(4), 353-358.

Susilomati, A., Wahyudi, AT., Lestari, Y., Suwanto, A. \& Wiyono S. (2011). Potential Pseudomonas isolated from soyben thizosphere as biocontrol against soil borne pytopathogenic fungi. Journal of Biosciences, 18, 51-56.

Tadesse, M., Lommen, W.J.M. \& Struik, P.C. (2001). Development of micropropagated potato plants over three phases of growth as affected by temperature in different phases. Netherland Journal of Agricultumal Science, 49(1), 53-66

Venter, S.I., Theron, D.J., Steyn, P.J., Ferreira, D.I. \& Eicker, A. (1992). A relationship between vegetative compatibility and pathogenicity of isolates of Fusarium oxysponum f.sp. tuberosi from potato. Pbytopathology, 82, 858-862.

Wolf, A., Fritze, A., Hagemann, M. \& Berg, G. (2002). Stenotrophomonas thirophila sp. nov., a novel plant-associated bacterium with antifungal properties. International Joumal of Systematic and Evolutionary Microbiology, 52(6), 1937-1944. 


\section{Uticaj Pseudomonas chlororaphis subsp. aurantiaca soja Q16 koji inhibira rast Fusarium oxysporum na prinos krompira}

\section{Dobrivoj Poštić - Dragana Jošić • Zorica Lepšanović • Goran Aleksić • Dragana Latković - Mira Starović}

Sažetak: U ovom radu je ispitan potencijal sojeva Pseudomonas chlororaphis koji produkuju antibiotike da povećaju prinos krompira $\mathrm{i}$ da inhibiraju razvoj micelije fitopatogene gljive Fusarium oxysporum (Fo) izolovane sa krompira. $P$. chlororaphis subsp. aurantiaca soj Q16 (PchlQ16) izazvao je najveću inhibiciju rasta micelije $(67,07 \%)$ gljive Fo izolata A2 in vitro. U poljskim ogledima utvrđivan je uticaj PchlQ16 na broj stabala po biljci, broj krtola i prosečnu masu krtole po biljci i ukupan prinos krompira sorte Rudolph. Primena PchlQ16 i broj tretmana imali su značajan uticaj na prinos krompira. PchlQ16 je povećao ukupan prinos krtola od 4,9\% do 33,05\% (dva tretmana), odnosno od 9,3\% do $92,35 \%$ (četiri tretmana) u poredjenju sa kontrolom. Na osnovu ovih rezultata preporučujemo primenu PchlQ16 četiri puta tokom vegetacionog perioda krompira. Rezultati in vitro ogleda u kojima je ovaj soj izvršio supresiju razvoja F. oxysporum podržavaju ovu preporuku. U ovom istraživanju pokazano je da PchlQ16 deluje kao efektivan stimulator rasta biljaka u proizvodnji krompira i može biti efikasan u prevenciji infekcije gljivom F. oxysporum.

Key words: Fusarium oxysponm, Pseudomonas chlororaphis, rizobacterija, Solanum tuberosum L., uticaj inhibicije 